\title{
Assessment of Social Vulnerability to Climate Change and Its Disaster Prevention in Pingtung County
}

\author{
Meng-Tsung Lee ${ }^{1}$, Kuo-Huan Ting ${ }^{2}$, Kun-Lung Lin ${ }^{3}$, Wen-Hong Liu ${ }^{2,3 *}$, Hao-Tang Jhan ${ }^{4}$ \\ ${ }^{1}$ Department of Marine Leisure Management, National Kaohsiung \\ Marine University, Kaohsiung City, Taiwan, ROC \\ ${ }^{2}$ Master Program of Marine Affairs and Business Management, National Kaohsiung Marine University, Taiwan, ROC \\ ${ }^{3}$ Department of Fisheries Production and Management, National Kaohsiung Marine University, Taiwan, ROC \\ ${ }^{4}$ School of Earth and Ocean Science, Cardiff University, UK \\ * Corresponding author
}

\begin{abstract}
Taiwan surrounded by water and has abundant and diversified marine environment and resources, so that Taiwanese life closely depends on marine and coast. However, with the increase of population and the change of economic structure led to the pressures on the coastal zone increase sharply in recent years. Meanwhile, owing to lack of comprehensive coastal development planning and the negative impact of climate change, the coastal environment and ecosystem have been affected seriously. Moreover, the impacts of climate change on the coastal zone not only affect the marine environment, ecology, and community of livelihood in marine activities but also have a strong effect for the sustainable development of national economics. Therefore, it is essential to develop social vulnerability assessment and establish adaptation measures in order to strengthen climate change adaptive ability. This study had carried out the social vulnerability assessment in Pingtung County to understand the exposure, self-protection capacity, and resilience to climate change in township level. The result shows that Jiadong Township (3.78), Checheng Township (3.67) and Manzhou Township (2.77) are the most vulnerable townships in Pingtung County due to the high exposure value (7.03, 6.74, 6.12). The results show the self-protection capability is the main factor of social vulnerability to disaster and the second is exposure. The effect of resilience is limited due to the value of different townships are similar. Therefore, Taiwanese government needs to improve and strengthen local disaster prevention system and self-protection capability, for example, informational system, mobilization system and inter-organization cooperation.
\end{abstract}

Keywords-climate change; social vulnerability assessment; indicator.

\section{INTRODUCTION}

In recent years, the issues of climate change and relevant risks have been investigated by researchers who are strive to adapt the impacts of climate change on various industries, regions and systems [1]. The impacts of climate change have gradually threatened to coastal areas in the world [2]. According to the global statistics, there is about $2 / 3$ major cities and $40 \%$ of population inhabit within 60 miles of shoreline areas $[3,4]$. Therefore, understanding of the vulnerability to climate change has high priority in coastal area. Taiwan surrounded by water and has abundant and diversified marine environment and resource, so that Taiwanese life closely depends on marine and coast. However, population growth and change in economic structure that leads to the development pressure on coastal area sharply increased over past few decades. To date, the communities who reside at land subsidence area on Taiwanese southwest coastal area is recognized as the first group of climate refugee under the threat of climate change. In addition, the area is flooding-prone area because land subsidence and multiple negative influences, for example: sea level rise, heavy rainfall, inundation and seawater overflow [5]. Therefore, the aim of this study is to explore the social vulnerability of Pingtung County to the impacts of climate change and raise the suggestion about the issue of disaster prevention in Taiwan.

\section{VULNERABILITY}

Vulnerability is a possibility of human and environment system suffers disaster and exposes to pressures which lead to the social and environmental condition change [6,7]. The vulnerability includes the degree of exposure to natural disasters, preparation and recovery capabilities to negative impacts [8]. Therefore, the notion of vulnerability is formed with exposure and susceptibility to external disturbances, resilience, and adaptive capacity $[9,10,11,12,13]$. Over the past few decades, vulnerability researches have begun to consider about how human system responses to environmental change, natural disasters and crisis that caused by human activities or the interaction between social and natural system $[11,12]$. In recent years, the notion of interaction between human and natural system leads to environmental change, natural disaster and human crisis has been realized [13]. Although not all of the human crisis are caused by environment changes, but the most of influence lead to great damages to human system because the human society is highly dependent on ecological system and environment $[14,15,16]$. Human is a component of the ecosystem, and therefore social system and natural system are inseparable [17]. Therefore, climate change 
vulnerability can be seen as a possibility of human-environment system suffers from the stresses of social and environment change [6]. Consequently, vulnerability is a result of the interaction of causal events, rather than a single result of a single event [18].

\section{VULNERABILITY ASSESSMENT}

Climate change vulnerability assessment not just simply analyzes vulnerability of specific communities or regions. Vulnerability assessment has greatly contributed to determine the particular requirements of various stakeholders and reduce their vulnerable characteristics to climate change $[6,7,11,12,13,19,20,21]$. Indicator method has been widely applied to measure vulnerability in different disciplines, including biophysical environment, education, technology and social characteristics [19]. Although the effectiveness of indicator method is limited by data availability, this method can be used to summarize data from different spatial scale and demonstrate the results to public [22]. The applicable indicators, available data and data quality are the significant elements in the process of vulnerability assessment [22].

\section{A. Indicator Selection}

These applicable indicators are selected base on the principle of data availability. Firstly, the group of candidate indicator was established according to relevant researches [6] and Modified Delphi Method is used to select the representative indicators. The Modified Delphi questionnaire used a 5-point Likert scale questionnaire in three rounds of surveys completed by exports. When the result regarding a specific indicator exceeded an average of 4 , the indicator was considered to achieve consensus and placed in the indicator group. If the average score of indicator less than 3.5 was eliminated, and an average between 3.5 and 3.9 was then used in the next round for reevaluation [23]. In addition, the Analytic Hierarchy Process (AHP) is used to analyze the weight value of each social vulnerability indicator before the indicators were aggregated. The result of indicator selection was shown in Table 1.

\section{B. Standardization}

Firstly, these indicators are divided into positive and negative indicators according to logical dichotomy and the value of indicators need to standardize. In order to sum up the value of indicator [24,25], all of the standardized value ( $Z$ score) are normalized and turned into positive value. The higher value of positive indicator shows the high vulnerability but the value of negative indicator have to convert into positive value (1-I value). The calculation formula is displayed as follows:
$Z_{j k}=\frac{X_{j k}-\bar{X}}{S_{j}}$

$\mathrm{Z}_{j k}$ : the standard score of ${ }_{j}$ indicator in $k_{k}$ township

$\mathrm{X}_{j k}$ : the value of $j$ indicator in $k$ township

$\mathrm{S}_{j}$ : the standard deviation of ${ }_{j}$ indicator in all of townships

$\bar{X}$ : the mean of $j$ indicator in all of townships

\section{Weighting}

The second part is to weight various indicators. The AHP Method of Multiple Criteria Decision Making (MCDM) can be used to gather together the opinion from exports, scholars, stakeholders and decision-makers to establish a hierarchical structure and simplify a complicated issue. Therefore, The AHP Method is conducted to measure the priority of importance level among these indicators and distribute the weights. The AHP questionnaires were sent to 15 exports and scholars and the survey period since $1^{\text {st }} \mathrm{July}$ to $31^{\text {st }}$ August in 2010 . The survey response rate is $100 \%$ and the data of completed questionnaires was collected and analyzed by the Expert Choice 2000. In order to verify the effectiveness of the questionnaire results, a consistency index (CI) was required to evaluate and judge the consistency of the overall hierarchical structure [26]. The optimal result is $\mathrm{CI}<0.1$. On the contrary, the result is ineffective when the $\mathrm{CI}>0.1$. The consistency is determined by Inconsistency Ratio (I.R.) in Expert Choice 2000 and critical value lower than 0.1 is optimal [27].

$I$ value times weight value is the AHP vulnerability value of every indicator and then sum up all of the AHP vulnerability value in order to calculate the vulnerability in different dimensions. The local vulnerability value needs to standardize and normalize again in order to compare the relative vulnerability of various townships. Finally, the levels of vulnerability are divided into 5 degree and the interval between every two degrees is 0.2 , hence the highest vulnerability is the value ranges between 0.8 and 1 . The analytic results can be used to draw the vulnerability classification maps. The calculation process is shown as follows:

$Z_{j k}-Z \quad \mathrm{I}_{j k}$ : the value of ${ }_{j}$ indicator in ${ }_{k}$ township $I_{j k}=\frac{Z_{j k}-Z_{j m}}{D_{j}} \quad \begin{aligned} & Z_{j k}: \text { the standard score of }{ }_{j} \text { indicator in }{ }_{k} \\ & \text { township }\end{aligned}$

$\mathrm{Z}_{j m}$ : the minimum value of ${ }_{j}$ indicator in all of townships

$\mathrm{D}_{j}$ : the range of standard score of ${ }_{j}$ indicator in all of townships (the maximum value minus minimum value)

\section{IV.RESULT}

Table 1 shows the ranking of weight value of the three dimensions in social vulnerability is self-protection capacity (0.399), resilience $(0.360)$ and exposure $(0.241)$. The self-protection capacity includes disaster prevention 
facilities (0.772) and medical assistance (0.228). The sub-dimensions of awareness of disaster prevention (0.647), economic structure (0.199) and education (0.154) are in resilience dimension. The exposure dimension contains social structure (0.418), underprivileged group (0.292), moveable and immovable property $(0.161)$ and economic construction (0.129) (Table 1). The six highest overall weight of indicators are awareness of disaster reduction (0.1078), the number of relief equipments (0.1007), risk perception $(0.0841)$, the number of emergency shelters $(0.0829)$, the coverage of police office and fire-brigade (0.0733), and the coverage of emergency shelters (0.0514).
The result shows that experts consider the concept of disaster prevention and preparation is more significant than others. Figure 1 demonstrates that Jiadong Township (3.78), Checheng Township (3.67) and Manzhou Township (2.77) are the most vulnerable townships in Pingtung County due to the high exposure value $(7.03,6.74,6.12)$ (Figure 1). Additionally, the self-protection capacity in Manzhou Township (-1.34), Fangliao Township (-1.38), and Linbian Township (-1.55) is weak (Table 2; Figure1). Finally, Table 2 and Figure 1 shows that the resilience is insufficient in Jiadong Township (-2.44), Linbian Township (-2.30) and Donggang Township (-2.35).

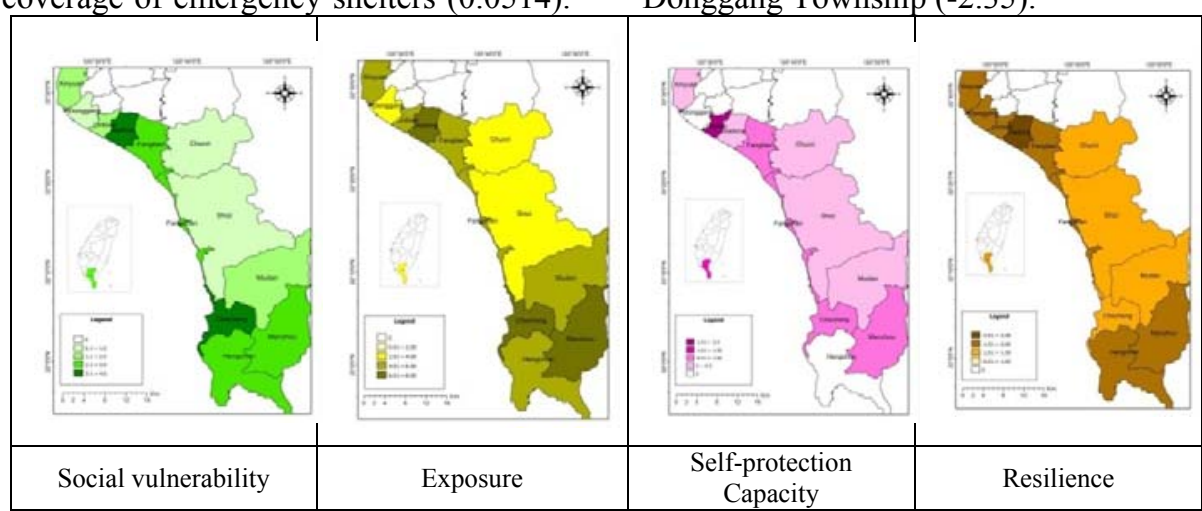

Figure 1. The degree of social vulnerability, exposure, self-protection capacity and resilience in township level of Pingtung County 
TABle I. The Weight And Overall Weight Of Dimension And Sub-Dimension

\begin{tabular}{|c|c|c|c|c|c|c|c|}
\hline Dimension & Weight & Sub-dimension & Weight & $\begin{array}{l}\text { Overall } \\
\text { Weight } \\
\end{array}$ & Indicator & Weight & $\begin{array}{l}\text { Overall } \\
\text { Weight } \\
\end{array}$ \\
\hline \multirow{8}{*}{$\begin{array}{l}\text { Self-Protection } \\
\text { Capacity }\end{array}$} & \multirow{8}{*}{0.399} & \multirow{4}{*}{$\begin{array}{l}\text { Disaster Prevention } \\
\text { Facilities }\end{array}$} & \multirow{4}{*}{0.772} & \multirow{4}{*}{0.308} & The number of relief equipments & 0.327 & 0.1007 \\
\hline & & & & & The number of emergency shelters & 0.269 & 0.0829 \\
\hline & & & & & $\begin{array}{l}\text { The coverage of police office and } \\
\text { fire-brigade }\end{array}$ & 0.238 & 0.0733 \\
\hline & & & & & The coverage of emergency shelters & 0.167 & 0.0514 \\
\hline & & \multirow{4}{*}{ Medical Assistance } & \multirow{4}{*}{0.228} & \multirow{4}{*}{0.091} & The coverage of medical institutions & 0.393 & 0.0358 \\
\hline & & & & & The number of medical staffs & 0.245 & 0.0223 \\
\hline & & & & & The number of medical institutions & 0.185 & 0.0168 \\
\hline & & & & & The number of sickbeds & 0.177 & 0.0161 \\
\hline \multirow{9}{*}{ Resilience } & \multirow{9}{*}{0.360} & \multirow{3}{*}{$\begin{array}{l}\text { Awareness of Disaster } \\
\text { Prevention }\end{array}$} & \multirow{3}{*}{0.647} & \multirow{3}{*}{0.2329} & Awareness of disaster reduction & 0.463 & 0.1078 \\
\hline & & & & & Risk perception & 0.361 & 0.0841 \\
\hline & & & & & Psychological susceptibility & 0.177 & 0.0412 \\
\hline & & \multirow{4}{*}{ Economic Structure } & \multirow{4}{*}{0.199} & \multirow{4}{*}{0.0716} & Disaster relief budget & 0.585 & 0.0419 \\
\hline & & & & & Social insurance & 0.214 & 0.0153 \\
\hline & & & & & Average annual income of household & 0.107 & 0.0077 \\
\hline & & & & & Employment rate & 0.095 & 0.0068 \\
\hline & & \multirow[b]{2}{*}{ Education } & \multirow[b]{2}{*}{0.154} & \multirow[b]{2}{*}{0.0554} & The ratio of high education population & 0.7 & 0.0388 \\
\hline & & & & & The ratio of illiterate & 0.3 & 0.0016 \\
\hline \multirow{12}{*}{ Exposure } & \multirow{12}{*}{0.241} & \multirow{4}{*}{ Social Structure } & \multirow{4}{*}{0.418} & \multirow{4}{*}{0.1007} & Aging index & 0.34 & 0.0343 \\
\hline & & & & & Population density & 0.329 & 0.0331 \\
\hline & & & & & Population growth rate & 0.173 & 0.0174 \\
\hline & & & & & Dependency ratio & 0.157 & 0.0158 \\
\hline & & \multirow{4}{*}{ Underprivileged Group } & \multirow{4}{*}{0.292} & \multirow{4}{*}{0.0704} & The ratio of female & 0.07 & 0.0049 \\
\hline & & & & & The ratio of independent elder & 0.458 & 0.0322 \\
\hline & & & & & The ratio of low-income household & 0.252 & 0.0177 \\
\hline & & & & & The ratio of disabled population & 0.221 & 0.0156 \\
\hline & & \multirow{2}{*}{$\begin{array}{l}\text { Moveable and Immovable } \\
\text { Property }\end{array}$} & \multirow{2}{*}{0.161} & \multirow{2}{*}{0.0388} & The number of house & 0.793 & 0.0308 \\
\hline & & & & & The number of vehicles & 0.207 & 0.0080 \\
\hline & & & & & The number of education institution & 0.76 & 0.0236 \\
\hline & & Economic Construction & 0.129 & 0.0311 & The number of government agencies & 0.24 & 0.0075 \\
\hline
\end{tabular}


TABle II. The Result Of Social VulnerabiLity To Climate Change In Township LeVEl of Pingtung County

\begin{tabular}{|c|c|c|c|c|c|c|c|c|c|c|c|c|c|}
\hline \multirow[b]{2}{*}{ Township } & \multirow[b]{2}{*}{$\begin{array}{c}\text { social } \\
\text { vulnerability }\end{array}$} & \multicolumn{3}{|c|}{ Dimension } & \multicolumn{9}{|c|}{ Sub-dimension } \\
\hline & & exposure & $\begin{array}{l}\text { self-protection } \\
\text { capacity }\end{array}$ & resilience & $\begin{array}{c}\text { social } \\
\text { structure }\end{array}$ & $\begin{array}{c}\text { Under } \\
\text { privileged group }\end{array}$ & $\begin{array}{l}\text { economic } \\
\text { construction }\end{array}$ & $\begin{array}{c}\text { moveable } \\
\text { and } \\
\text { immovable } \\
\text { property }\end{array}$ & $\begin{array}{c}\text { medical } \\
\text { assistance }\end{array}$ & $\begin{array}{l}\text { disaster } \\
\text { prevention } \\
\text { facilities }\end{array}$ & $\begin{array}{l}\text { economic } \\
\text { structure }\end{array}$ & education & $\begin{array}{c}\text { awareness } \\
\text { of } \\
\text { disaster } \\
\text { prevention }\end{array}$ \\
\hline Jiadong & 3.78 & 7.03 & -0.81 & -2.44 & 6.56 & 0.19 & 0.15 & 0.13 & 0.000 & -0.81 & -0.090 & -1.66 & -0.694 \\
\hline Checheng & 3.67 & 6.74 & -1.19 & -1.89 & 6.34 & 0.12 & 0.16 & 0.12 & 0.000 & -1.19 & -0.090 & -1.21 & -0.582 \\
\hline Manzhou & 2.77 & 6.12 & -1.34 & -2.00 & 5.58 & 0.26 & 0.15 & 0.12 & 0.000 & -1.34 & -0.086 & -1.30 & -0.611 \\
\hline Fangliao & 2.25 & 5.76 & -1.38 & -2.13 & 5.05 & 0.35 & 0.23 & 0.13 & -0.009 & -1.37 & -0.091 & -1.44 & -0.605 \\
\hline Fangshan & 2.05 & 5.24 & -1.15 & -2.04 & 4.78 & 0.19 & 0.15 & 0.12 & 0.000 & -1.15 & -0.084 & -1.25 & -0.698 \\
\hline Hengchun & 2.04 & 4.58 & -0.33 & -2.20 & 3.58 & 0.48 & 0.38 & 0.14 & -0.013 & -0.32 & -0.089 & -1.49 & -0.620 \\
\hline Linbian & 2.00 & 5.85 & -1.55 & -2.30 & 5.33 & 0.12 & 0.27 & 0.13 & 0.016 & -1.57 & -0.087 & -1.60 & -0.619 \\
\hline Xinyuan & 1.61 & 4.60 & -0.82 & -2.17 & 4.08 & 0.16 & 0.22 & 0.14 & 0.000 & -0.82 & -0.093 & -1.45 & -0.633 \\
\hline Mudan & 1.53 & 4.05 & -0.67 & -1.84 & 3.64 & 0.10 & 0.19 & 0.12 & 0.000 & -0.67 & -0.089 & -1.03 & -0.724 \\
\hline Chunri & 0.67 & 2.93 & -0.50 & -1.77 & 2.58 & 0.10 & 0.13 & 0.12 & 0.007 & -0.50 & -0.082 & -0.95 & -0.737 \\
\hline Shizi & 0.37 & 3.07 & -0.76 & -1.94 & 2.64 & 0.12 & 0.19 & 0.12 & -0.002 & -0.75 & -0.090 & -1.20 & -0.643 \\
\hline Donggang & 0.26 & 2.74 & -0.12 & -2.35 & 1.98 & 0.22 & 0.39 & 0.15 & -0.019 & -0.10 & -0.091 & -1.64 & -0.625 \\
\hline average value & 1.917 & 4.893 & -0.885 & -2.089 & 4.345 & 0.201 & 0.218 & 0.128 & -0.002 & -0.883 & -0.089 & -1.352 & -0.649 \\
\hline
\end{tabular}




\section{DISCUSSION AND RECOMMENDATION}

The specific communities need particular adaptation actions according to socio-economic condition and physical characteristics. The prevention and mitigation of natural disaster not only need to focus on hydrology and atmospheric factors. In addition, the economic, social and political factors also affect the community's adaptive capacity and strengthen the influence degree of hazard event. Therefore, it is necessary to understand the interaction of specific vulnerability factors in order to develop effective adaptation strategies [19]. The results of this study show the self-protection capability is the main factor of social vulnerability and the second is exposure. The effect of resilience is limited due to the value of different townships are similar. Therefore, Taiwanese government needs to improve and strengthen local disaster prevention system and self-protection capability in the future. Local government should establish specific disaster relief and prevention system for different requirement of specific communities concerning the degree of self-protection capacity [21]. Take resilience as an example, the budget and manpower arrangement for post-disaster reconstruction should concern the resilience of different communities and areas, so that the economically disadvantaged groups can obtain enough support. There are three key elements in Taiwanese disaster relief: informational system, mobilization system and inter-organization cooperation [28]. In order to effectively carry out the command, an official information integration platform and overall planning information and communication system is essential to effectively transmit the information. In the mobilization system, the Central Emergency Operation Center should establish an organization responsible for mobilization. Meanwhile, existing exercises mechanisms can be used to strengthen the hazard prevention. Inter-organization cooperation mechanisms should be established and link central and local government, local government and local government, government and NGOs, and international cooperation mechanisms. In addition, government departments should form a network system to strengthen the support and coordination capability of inter-organizations and inter-regions.

Furthermore, the improvement of disaster prevention energy at basic level is able to enhance the immediate effect of disaster prevention. However, many communities in Taiwan lack for the related information and training of disaster prevention. For this reason, the government needs to assist local communities in improving awareness and function of disaster prevention, and constructing an appropriate connection with central disaster prevention systems to advance the capacity of disaster preparedness and response in basic level [29].

\section{VI.ACKNOWLEDGEMENTS}

The research work was supported by Ministry of Science and Technology of Taiwan under Grant NSC 101-2410-H-022 -003 -

\section{REFERENCE}

[1] Urwin, K. \& Jordan. A. Does public policy support or undermine climate change adaptation? Exploring policy interplay across different scales of governance. Global Environmental Change, 18, pp. 180-191, 2008.

[2] Tribbia, J. \& Moser, S.C. More than information: what coastal managers need to plan for climate change. Environmental Science \& Policy, 11(4), pp. 315-328, 2008.

[3] Cai, F., Su, X., Liu, J., Li, B. \& Lei, G. Coastal erosion in China under the condition of global climate change and measures for its prevention. Progress in Natural Science, 19, pp. 415-426, 2009.

[4] Dow, K. \&Downing, T.E. The Atlas of climate change. London: Earthscan; 2007

[5] Wang, Y.C., Yu, C.Y. \& Lin, P.L. The Social Impacts on the Economically Vulnerable from Threat of Flooding: the case of Finishing Villages in the West Coast of Taiwan. Taiwanese Social Work, 11, pp. 81-113, 2013. in Chinese.

[6] Schröter, D., Polsky, C. \& Patt, A.G. Assessing vulnerabilities to the effects of global change: an eight step approach. Mitigation and Adaptation Strategies for Global Change, 10, pp.573-595, 2005.

[7] Klein, R.J.T. \& Nicholls, R.J. Assessment of coastal vulnerability to climate change. Ambio, 28, pp.154-181, 1999.

[8] Pelling, M. Vulnerability of cities. London: Earthscan, 2003.

[9] Adger, W.N. Vulnerability. Global Environmental Change, 16, pp.268-281, 2006.

[10] Burton, I., Kates, R.W. \& White, G.F. The environment as hazard. New York: Guildford, 1993.

[11] Cutter, S.L. Vulnerability to environmental hazards. Progress in Human Geography, 20(4), pp. 529-539, 1996.

[12] Cutter, S.L, Boruff, B.J. \& Shirley, W.L. Social vulnerability to environmental hazards. Social Science Quarterly, 54(2), pp. 242-261, 2003.

[13] Schröter, D. Our vulnerability to changes in ecosystem services. Assessing Vulnerability to Global Environmental Change. Edited by Patt, A.G., Schrőter, D., Klein, R.J.T. \& Cristina de la Vega-Leinert, A. London: Earthscan, 2009.

[13] Turner, B.L., Kasperson, R.E., Matson, P., McCarthy, J.J., Corell, R.W., Christensen, L., Eckley, N., Kaserson, J.X., Luers, A., Martello, M.L., Polsky, C., Pulsipher, A. \& Schiller, A. A framework for vulnerability analysis in sustainability science. United States of America: Proceedings of the National Academy of Sciences, 100, pp. 8074-8079, 2003.

[15] De Groot, R.S. Functions of nature: Evaluation of nature in environmental planning. Management and decision-making. Groningen: Wolters-Noordhoff BV, 1992.

[16] Daily, G.C. Nature's services. Washington DC: Island Press/Shearwater Books; 1997.

[17] Daily, G.C. \& Ellison, K. The new economy of nature: The quest to make conservation profitable. Washington DC: Island Press/Shearwater Books, 2002.

[18] Ribot, J.C., Najam, A. \& Watson, G. Climate variation, vulnerability and sustainable development in the semi-arid tropics. The Earthscan Reader on Adaptation to Climate Change. Edited by Lisa, E., Schipper, F. \& Burton, I. London: Earthscan, 2009.

[19] Yohe, G. \& Tol, R.S.J. Indicators for social and economic coping capacity: Moving toward a working definition of adaptive capacity. Global Environmental Change, 12(1), pp. 25-40, 2002.

[20] Tapsell, S. \& McCarthy, S. Social vulnerability to natural hazards. London: Flood Hazard Research Centre, Middlesex University, 87, 2010.

[21] Li, H.C., Yang, H.H., Liao, K.M. \& Shaw, D.G. Constructing social vulnerability index of flood disaster. Journal of Architecture and Planning, 10(3), pp. 163-182, 2010. in Chinese.

[22] Leichenko, R. \& O'Brien, K. Mapping Double Exposure to climate change and trade liberalization as an awareness-raising tool. 
Assessing Vulnerability to Global Environmental Change. Edited by Patt, A.G., Schröter, D., Klein, R.J.T. \& Cristina de la Vega-Leinert, A. London: Earthscan, 2009.

[23] Dixon, E., Armstrong, C., Maddern, G., Sutherland, F., Hemming, A., Wei, A., Sherman, M., Moore, M., Mckay, A., Urbach, D., Labrie, M., Gordon, L., Barkun, J., Quan, M.L., Dowden, S., Bigam, D. \& Gallinger, S. Development of quality indicators of care for patients undergoing hepatic resection for metastatic colorectal cancer using a Delphi process. Journal of Surgical Research, 156(1), pp.32-38, 2009.

[24] Wu, J.Y. \& Chiang, I.C. The development and analysis on natural disaster statistics index system in Taiwan. Journal of Geographical Science, 51, pp.65-84, 2008. In Chinese.
[25] Chen, I.C., Li, H.C., Su, W.J. \& Tasi, Y.F. Using AHP to map flood vulnerability of Ping-Tung Coastal Area. Taiwan Water Conservancy, 59(4), pp. 30-46, 2011.

[26] Deng, J.Y. Project evaluation: methods and applications. Taipei: Logistics Planning and Management Research Center; 2005.

[27] Saaty, T.L. \& Forman, E.H. The hierarchon: A dictionary of hierarchies. RWS Publication, 5, pp.496, 1996.

[28] Yang, Y.N. Research on Disaster Rescue System: The 88 Flood Case in Taiwan. Journal of Public Administration, 32, pp.143-169, 2009. in Chinese.

[29] Shi, B.C., Ke, S.S., Hu, Q.L., Chuang, M.J. \& Chang, H.Y. The reflection on disaster rescue and prevention system after 88 flood. The magazine of The Chinese Institute of Civil and Hydraulic Engineering, 37(1), pp.48-56, 2011. in Chinese. 